\title{
Studies and Research Regarding Several Tomato Accessions Behaviour in Thermo-Hydric Stress
}

\author{
Costel VINATORU ${ }^{1)}$, Bianca ZAMFIR ${ }^{1)}$, Camelia BRATU ${ }^{1)}$, Elena CHIRA $^{2)}$ \\ ${ }^{1)}$ Vegetable Research and Development Station Buzau, Romania; \\ ${ }^{2)}$ Institute of Vegetable and Floriculture Research and Development Vidra, Romania . \\ ${ }^{*}$ Corresponding author, e-mail: costel_vinatoru@yahoo.com
}

Bulletin UASVM Horticulture 72(1) / 2015

Print ISSN 1843-5254, Electronic ISSN 1843-5394

Doi:10.15835/buasvmcn-hort:10439

\begin{abstract}
Tomatoes are the most important vegetable species, both in the world and in our country. In the last decades, the breeders have obtained hundreds of varieties or hybrids for growing in open field, plastic tunnels or glasshouse. In 1975-1990 period, at Research Institute for Vegetables and Flowers Growing were drawn up breeding teams that have achieved some new valuable varieties. After 1990 year, breeding activity was decreased and only stayed at Research Station for Vegetable Buzău. Breeders of this station have obtained new outstanding varieties and hybrids with high yielding potential and good quality. For the future, it is necessary to form new teams well prepared and should more funds, with clear objectives in order to obtain new required cultivars for growers and consumers. The new cultivars have to be more resistant pathogens and adverse environmental conditions. The current climatic conditions materialized through sudden changes from day to day and even from one hour expose plants to extreme survival conditions, causing major damage, sometimes completely. The germplasm resource of S.C.D.L. Buzău currently contains in this species a number of over 700 genotypes with distinct expressiveness. Annually, it is made an evaluation of each cultivar following the purpose of achieving genetic resistant accessions.

Keywords: tomato, thermo-hydric stress, variant.
\end{abstract}

\section{INTRODUCTION}

Research into plant response to water stress is becoming increasingly important, as most climate-change scenarios suggest an increase in aridity in many areas of the globe (Chaves,2003). Thermo hydric stress resistant plants have the ability to initiate defence reactions that allow them to survive in these conditions, (Burzo 2011). Boyer (1982) considers that hydric stress is widely spread and represents the most important abiotic limiting factor for most plants. Lin and Key (1984) argued that heat stress acclimatization can be achieved by exposing plants to a low heat shock. Heat stress is a major limiting growth in many plant species and areas (Morales, 2003).

\section{AIMS AND OBJECTIVES}

As a result of emphasizing this phenomenon generated by climate change, Genetics, Breeding and Biodiversity Conservation Laboratory at V.R.D.S. Buzau introduced as a new breeding purpose since 2010, genetic heritage evaluation preserved in the germplasm collection units under thermo hydric stress conditions and identification of genetic resistant accessions.

\section{MATERIALS AND METHODS}

The species taken into study was the tomato, due to the fact that the unit possesses a solid germplasm collection in this species, consisting of over 700 accessions and a total of 14 approved and patented biological creations. 
Tab 1. Yield/plant for the studied lines on the three variants.

\begin{tabular}{|c|c|c|c|c|c|c|c|c|c|c|c|c|c|}
\hline $\begin{array}{l}\text { Plant } \\
\text { yield } \\
(\mathrm{kg})\end{array}$ & \multicolumn{2}{|c|}{ L 101} & L102 & L100 & L778 & L 25 & L10A & L10B & L 42 & L 55 & $\begin{array}{c}\mathrm{L} \\
2000 \\
\mathrm{~A}\end{array}$ & $\begin{array}{c}\mathrm{L} \\
2000 \\
\mathrm{~B}\end{array}$ & $\begin{array}{c}L \\
2000 \\
C\end{array}$ \\
\hline \multirow[t]{3}{*}{ Variant 1} & $\mathrm{x}$ & 2,8 & 3,1 & 2,9 & 2,7 & 2,2 & 3,5 & 3,3 & 3,2 & 3,4 & 2,3 & 2,1 & 2,2 \\
\hline & $\mathrm{s}$ & 1.0 & 0.7 & 1.2 & 1.2 & 0.9 & 1.2 & 1.2 & 1.0 & 1.6 & 0.5 & 1 & 1.1 \\
\hline & $\mathrm{x}-\mathrm{S}$ & $\begin{array}{l}1.8- \\
3.8\end{array}$ & $\begin{array}{c}2.4- \\
3.8\end{array}$ & $\begin{array}{l}1.7- \\
4.1\end{array}$ & $\begin{array}{l}1.5- \\
3.9\end{array}$ & $\begin{array}{l}1.3- \\
3.1\end{array}$ & $\begin{array}{c}2.3- \\
4.7\end{array}$ & $\begin{array}{c}2.1- \\
4.5\end{array}$ & $\begin{array}{c}2.2- \\
4.2\end{array}$ & $\begin{array}{c}1.8- \\
5.0\end{array}$ & $\begin{array}{l}1,8- \\
2.8\end{array}$ & $\begin{array}{l}1.1- \\
3.1\end{array}$ & $\begin{array}{c}1.1- \\
3.3\end{array}$ \\
\hline \multirow[t]{3}{*}{ Variant 2} & $\mathrm{x}$ & 1,2 & 1,7 & 1,6 & 1,1 & 1,3 & 2,1 & 1,6 & 1,5 & 1,8 & 1,9 & 1,7 & 1,9 \\
\hline & $\mathrm{S}$ & 0.8 & 0.9 & 1.0 & 0.7 & 0.9 & 1.1 & 1.0 & 0.8 & 1.2 & 0.6 & 1 & 0.7 \\
\hline & $\mathrm{x}-\mathrm{S}$ & $\begin{array}{c}0.4- \\
2 \\
\end{array}$ & $\begin{array}{l}0.8- \\
2.6 \\
\end{array}$ & $\begin{array}{c}0.6- \\
2.6 \\
\end{array}$ & $\begin{array}{c}0.4- \\
1.8 \\
\end{array}$ & $\begin{array}{c}0.4- \\
2.2 \\
\end{array}$ & $1-3.2$ & $\begin{array}{l}0.6- \\
2.6\end{array}$ & $\begin{array}{c}0.7- \\
2.3 \\
\end{array}$ & $\begin{array}{c}0.6- \\
3.0\end{array}$ & $\begin{array}{c}1,3- \\
2.5 \\
\end{array}$ & $\begin{array}{c}0.7- \\
2.7 \\
\end{array}$ & $\begin{array}{l}1.2- \\
2.6\end{array}$ \\
\hline \multirow[t]{3}{*}{ Variant 3} & $\mathrm{x}$ & - & - & 0,3 & - & - & 0,4 & - & - & - & 0.8 & - & 0.5 \\
\hline & $\mathrm{S}$ & - & - & 0.1 & - & - & 0.3 & - & - & - & 0,3 & - & 0,1 \\
\hline & $\mathrm{x}-\mathrm{S}$ & - & - & $\begin{array}{c}0.2- \\
0.4\end{array}$ & - & - & $\begin{array}{c}0.1- \\
0.7\end{array}$ & - & - & - & $\begin{array}{c}0.5- \\
1.1\end{array}$ & - & $\begin{array}{c}0,4- \\
0,6\end{array}$ \\
\hline
\end{tabular}

Note: $\mathrm{x}$ - average; s- standard deviation.

Research started in 2010 by mounting the 3 experimental variants: V1- constantly irrigated V2-irrigated when needed and non-irrigated-V3. The cultivation technology applied was the specific one for indeterminate and determinate tomato crops and the water supply of the crop was made according to the experimental variants.

Results: After a 3 years evaluation of genetic material we selected a number of 6 indeterminated accessions and 6 determinated accessions that showed genetic superiority in terms of resistance to thermo hydric stress. The evaluation of the lines has been carried out in accordance with the climate data recorded during the period of vegetation.

The analysis carried out highlighted that in variant 1 and 2 of line $10 \mathrm{~A}$ ranked first with a yield of $3,5 \mathrm{~kg} /$ plant and $2.1 \mathrm{~kg} /$ plant. In what concerns the third variant, it shows clearly that without irrigation, no line could resist (tab. 1.).

The lines which demonstrated resistance to thermo hydric stress were obtained in the area of Buzau and the breeding process followed the objective of imprinting resistance to the environmental conditions.

\section{CONCLUSION}

Breeding classical methods are limited in terms of imprinting resistance at thermo hydric stress, requiring a much longer period of time. It has been demonstrated that in a non-irrigated crop such as V3, no studied cultivar resisted at the action of natural thermo hydric stress. It showed that the genetic heritage, intensity and duration of thermo hydric stress play an important role in achieving this objective; the differentiation was achieved in variant 2 .

\section{REFERENCES}

1. Boyer (1982), Plant productivity and environment . Science, 218, 443-448

2. Burzo (2011), Thermo-hydric stress on tomato, Ceres, 53.

3. Chaves M. Manuela, Maroco Joao P., Pereira S. Joao,(2003) Understanding plant resonses to drought-from genes to the whole plant, Functional Plant Biology Lisboa, Portugal, p.239-264.

4. D. Morales, P. Rodríguez, J. Dell’Amico, E. Nicolás, A. Torrecillas, M.J. Sánchez-Blanco,(2003), HighTemperature Preconditioning and Thermal Shock Imposition Affects Water Relations, Gas Exchange and Root Hydraulic Conductivity in Tomato, Biologia Plantarum, vol. 47., p 203-208, Spain.

5. Lin, Key (1984), Plant Physiology, 152-160. 